\title{
An Approach to the Measurement of Intangible Assets in dot com
}

Carlos Serrano Cinca. Universidad de Zaragoza. Spain. serrano@unizar.es

Yolanda Fuertes Callén. Universidad de Zaragoza. Spain. yfuertes@unizar.es

Cecilio Mar Molinero ${ }^{1}$ Universidad Politécnica de Cataluña. Spain. mar@ioc.upc.es

\begin{abstract}
A sample of 40 firms that operate on the Internet is studied to explore ways of identifying and measuring intangible assets in this area of business. The firms meet three conditions: operate on the Internet, have available accounting information, and are quoted on the stock exchange. Data was obtained for four web metrics indicators, 30 ratios that combine accounting and web traffic information, and a measure of efficiency based on Data Envelopment Analysis. Modelling relied on multivariate statistical approaches. Two intangible assets were identified: one was related to internal structure and was associated with managerial efficiency in achieving an impact in the Internet; and another one was associated with external image and customer loyalty.
\end{abstract}

Key words: Dot com, Intangible Assets, Multidimensional Scaling, Data Envelopment Analysis.

\footnotetext{
Cecilio Mar Molinero was a Professor on Sabbatical leave at the University of Zaragoza with a grant from the programme "Ayudas para estancias de profesores, investigadores, doctores y tecnólogos en España" funded by the Secretaría de Estado de Educación y Universidades.
} 


\section{INTRODUCTION}

The third computing revolution is characterised by the emergence of a new way of doing business: the dot com company. The objective of a company in this new economy continues to be the same as the objective of a traditional company: to make profit for its shareholders. The traditional inputs that are required in the production process, the four m's (men, machines, money and materials), are no longer sufficient to describe a dot com company. In the dot com company new inputs in the form of intangible assets assume a fundamental role. Many recent papers have dealt with this sector of activity: Higson and Briginshaw (2000), Schwartz and Moon (2000) Trueman et al (2000 and 2001), Demers and Lev (2001), Damoradan (2001), Davila and Venkatachalam (2001), Hand (2001), Bartov et al (2002), and Davis (2002).

Intangible assets are particularly important in the dot com world. These include such diverse terms as intellectual capital, human capital, internal organisation, customer loyalty, brand names, etc. It is, therefore, important to acknowledge and value such intangible assets, both to improve internal decision making, and to prove its potential to the outside world. Thus, new indicators need to be developed to complement traditional measures of performance based only on financial information. Pioneering work in the study of intangible assets and intellectual capital has been done by Brooking (1996), Sveiby (1997), Edvinsson and Malone (1997), and Stewart (1998). In parallel with these theoretical studies, there have been many reports of empirical work on intangible assets. Examples are Amir and Lev (1996), Aboody and Lev (1998), Barth and Clinch (1998), Lev (1999), Kristen and Gregory (1999), and Deng et al. (1999).

When a new line of business appears in the market, particularly one with low barriers of entry, many companies are formed at the early stages but few reach maturity. Take, for example, the automotive business, which emerged at the end of the nineteenth century. Out of the hundreds of new firms created at that time one could name Benz, Panhard, Mors, and Renault. Some of these are still household names, but most went by the roadside. To have a good product is not enough to guarantee survival. Who would have predicted the disappearance of a mythical name such as Hispano-Suiza or Oldsmobile?. Now, one hundred years later, half a dozen players hold most of the motorcar market. A similar dynamic 
is taking place in the Internet world: many firms have emerged, some have failed, many will go, and, probably, only a few will survive.

This paper will attempt to identify and measure intangible assets on the basis of financial and non-financial information. To do this, we need to identify the relevant non-financial information in a dot com company. This is an aspect that has been recently studied; examples are Amir and Lev (1996) in the wireless communications industry; Hand (2001) in U.S. Internet Stocks; and Jorion and Talmor (2001) in emerging industries. Intangible assets, however, may not explain all irregular behaviour. Lev (2002) argues that Enron's failure, requires more than their presence or absence.

Dot com companies are very young, and there has not been enough time to develop a history of useful financial data. This is where non-financial indicators become important. Some non-financial performance indicators have been proposed. Non-financial indicators in the dot com world are usually "web metrics". Some empirical studies that have concentrated on the relevance of web metrics are Hand (2001), Damoradan (2001), Alpar et al. (2001), Davila and Venkatachalam (2001) and Keating et al. (2003). Examples of web metrics are the number of "unique visitors", "page hits", or "reach". These indicators will be defined below. Some of these indicators are really trying to measure intangible assets such as brand name, potential customers or loyalty. Is there a way of measuring intangible assets or, at least, of ordering companies according to the level of certain intangible assets?.

A related set of questions relates to the efficiency with which inputs in a dot com company are converted into output. This was explored by means of Data Envelopment Analysis (DEA), a Linear Programming based approach to comparative efficiency measurement (Norman and Stocker, 1991).

This study will use accounting information, traffic measures, and ratios that combine both on a sample of 40 dot com companies in order to identify some intangible assets. Section 2.1 describes the sample and its characteristics. Section 2.2 is devoted to the variables included and also contains a discussion on indicators of Internet traffic intensity. Section 2.3 gives a summary account of DEA efficiency modelling. Section 3 reports the analysis, which is based on multivariate statistical methods: multidimensional scaling (MDS) and property fitting techniques (PF). 
These tools will serve to convert observable variables into measurements of intangible factors. A conclusion section completes the paper.

\section{MEASURING DEA EFFICIENCY IN INTERNET COMPANIES}

This section concentrates on the study of efficiency in dot com firms using Data Envelopment Analysis (DEA). An important decision in DEA modelling is the selection of inputs and outputs that are included in the specification. In this paper, financial and business information are used as inputs and web metrics are used as outputs in the assessment of efficiency.

\subsection{Firms in the sample}

To be included in the sample, companies had to satisfy three conditions: (1) have available relevant web traffic measurements, (2) be listed on the stock market as an Internet company, and (3) file a 10-K with the Securities Exchange Commission (SEC).

It is not always easy to assess if a company belongs to the Internet sector. This can be established using several criteria such as the origin of the revenues commissions, advertising revenues, on line sales-, the nature of business -which expands from Internet portals to E-tailers-, or taking into account the nature of the commercial partners -some operate from business to business, or "B2B"; other, from business to consumer, or "B2C"-. Some firms do not operate at all in the Internet. These are known as "Brick and Mortar". Other firms, known as "Pure Players" operate solely in the Internet. Many, however, are some way between these two extremes, "Brick and Click".

Even within firms devoted to Internet business, it is possible to identify many e-business models. The Internet Stock List, whose web address is (http:// www.internetstocklist.com), classifies net firms into a series of categories such as: Search/portals, gateways to the Internet, which obtain finance from advertising; Content/community, which try to cater for individuals with shared interests, sometimes financed through advertising revenues and sometimes through membership fees; E-tailers, which engage in retail sales through the net; Financial 
services via the Internet; E-commerce enablers, which sell software enabling electronic commerce; Security, specialising in software for electronic security; Performance software, which also specialise in software for the net; Internet services, specialising in services such as web site hosting; Advertising, specialists in marketing through the net; Consultants/designers, providing consultancy on Internet matters; Speed/bandwidth, concerned with improved net performance; ISP, provide Internet access. These groups can be really further classified into three kinds of companies: those that provide the basic infrastructure for the net, those that provide contents for websites, and those that try to sell through the net.

The first condition for inclusion in the sample of companies was that the company should belong to the Internet sector and that it should have available web traffic measurements (web metrics). Demers and Lev (2001) argue that web metrics play an important economic role in e-tail, content/communities, financial news/services, portal and services. In this paper, only three areas of Internet activities have been included: e-tail, content/communities, and search/portals. Web metrics plays an important economic role in all three. Can these areas of activity be treated as being equivalent or are there differences between them on the basis of the chosen variables?. Such web traffic indicators are collected, processed, and published by several digital media audience firms. Web metrics were obtained from Pcdataonline.com, which is today known as NetScore ${ }^{\circledR}$, an Internet Traffic Measurement Service from comScore, a leading firm in audience measurement (http://www.comscore.com) NetScore ${ }^{\circledR}$ uses panel-based methods to obtain the data, and claims that its panels include over 1.5 million people. The data contains observations for each company on 31st March. March was chosen in order to avoid end of year effects relating to the holiday period of Christmas and the New Year. It has the further advantage of linking with financial information, which tends to be published around these dates.

The second condition for inclusion in the sample is to be listed on the stock exchange. This was found by checking with the Internet Stock List (http:// www.internetstocklist.com).

The third condition was that accounting information should be available. Annual reports and accounts were collected from the Securities and Exchange Commission, (http://www.sec.gov). 
A total of 40 firms were found to meet all the required conditions. For a list of the companies involved see Table 1 . Table 1 shows the stock exchange ticker, the area of activity according to the Standard Industrial Classification (SIC), and the web address for the company.

\begin{tabular}{|c|c|c|c|}
\hline Ticker & Web address & SIC CODE & Efficiency \\
\hline ADBL & http://www.audible.com & SIC-7389 Business Services & $8 \%$ \\
\hline AHWYQ & http://www.audiohighway.com & SIC-7374 Computer Processing & $35 \%$ \\
\hline ALOY & http://www.alloy.com & SIC-5961 Catalog \& Mail-Order Houses & $21 \%$ \\
\hline AMEN & http://www.crosswalk.com & SIC-7371 Computer Programming Services & $12 \%$ \\
\hline AMZN & http://www.amazon.com & SIC-5961 Catalog \& Mail-Order Houses & $8 \%$ \\
\hline ASKJ & http://www.ask.com & SIC-7389 Business Services & $100 \%$ \\
\hline BGST & http://www.bigstar.com & SIC-5961 Catalog \& Mail-Order Houses & $31 \%$ \\
\hline $\mathrm{BNBN}$ & http://www.barnesandnoble.com & SIC-5735 Retail-Record \& Prerecorded Tape Stores & $16 \%$ \\
\hline BOUT & http://www.about.com & SIC-7370 Services-Computer Programming & $99 \%$ \\
\hline BUYX & http://www.buy.com & SIC-5734 Computer \& Computer Software Stores & $18 \%$ \\
\hline CDNW & http://www.cdnow.com & SIC-5735 Record \& Prerecorded Tape Stores & $34 \%$ \\
\hline CNET & http://www.cnet.com & SIC-7812 Motion Picture and Video Tape Prod. & $42 \%$ \\
\hline EBAY & http://www.ebay.com & SIC-7389 Business Services & $100 \%$ \\
\hline EDGR & http://www.edgaronline.com & SIC-7389 Business Services & $13 \%$ \\
\hline EGGS & http://www.egghead.com & SIC-5961 Catalog \& Mail-Order Houses & $8 \%$ \\
\hline FASH & http://www.fashionmall.com & SIC-5949 Sewing, Needlework & $17 \%$ \\
\hline FATB & http://www.fatbrain.com & SIC-5990 Retail Stores & $3 \%$ \\
\hline GOTO & http://www.goto.com & SIC-7389 Business Services & $65 \%$ \\
\hline HITS & http://www.musicmaker.com & SIC-5961 Retail-Catalog \& Mail-Order Houses & $10 \%$ \\
\hline INSW & http://www.insweb.com & SIC-7389 Business Services & $20 \%$ \\
\hline IVIL & http://www.ivillage.com & SIC-2721 Periodicals, Paper & $17 \%$ \\
\hline KOOP & http://www.drkoop.com & SIC-8090 Miscellaneous Health and Allied Services & $42 \%$ \\
\hline LFMN & http://www.lifeminders.com & SIC-7389 Services-Business Services & $100 \%$ \\
\hline LOOK & http://www.looksmart.com & SIC-7374 Computer Processing and Data Prep. & $39 \%$ \\
\hline MCNS & http://www.mediconsult.com & SIC-7310 Services-Advertising & $9 \%$ \\
\hline MKTW & http://www.marketwatch.com & SIC-7374 Computer Processing and Data Prep. & $29 \%$ \\
\hline MQST & http://www.mapquest.com & SIC-7374 Computer Processing and Data Prep. & $97 \%$ \\
\hline MTHR & http://www.mothernature.com & SIC-5412 Retail-Convenience Stores & $27 \%$ \\
\hline NBCI & http://www.nbci.com & SIC-7389 Business Services & $9 \%$ \\
\hline ONHN & http://my.webmd.com & SIC-7372 Services-Prepackaged Software & $100 \%$ \\
\hline SPLN & http://www.sportsline.com & SIC-7374 Computer Processing and Data Prep. & $34 \%$ \\
\hline
\end{tabular}




\begin{tabular}{l|l|l|c}
\hline SWBD & http://www.switchboard.com & SIC-7389 Services-Business Services & $98 \%$ \\
TGLO & http://www.theglobe.com & SIC-7310 Services-Advertising & $47 \%$ \\
TMCS & http://www.ticketmaster.com & SIC-7990 Services-Miscellaneous Amusement & $17 \%$ \\
TSCM & http://www.thestreet.com & SIC-2711 Newspapers: Publishing or Publishing & $12 \%$ \\
TVLY & http://www.travelocity.com & SIC-6770 Blank Checks & $100 \%$ \\
UBID & http://www.ubid.com & SIC-5961 Retail-Catalog \& Mail-Order Houses & $29 \%$ \\
UPRO & http://www.uproar.com & SIC-7374 Computer Processing and Data Prep. & $100 \%$ \\
WOMN & http://www.women.com & SIC-2741 Miscellaneous Publishing & $39 \%$ \\
YHOO & http://www.yahoo.com & SIC-7373 Services-Computer Integrated Sys. Design & $100 \%$ \\
\hline
\end{tabular}

Table 1. Companies in the sample. DEA efficiency estimates.

\subsection{Variables in the model}

From NetScore ${ }^{\circledR}$, information was obtained on reach, page hits, unique visitors, and time spent. These variables are defined by NetScore ${ }^{\circledR}$ as follows.

"Reach: Measures the proportion of Internet-using machines visiting a given domain. It is expressed as the total number of machines visiting the specified domain divided by the number of machines visiting any site on the Internet over the analysis period.

Page Hits: Measures the opportunity for a page to appear in a browser window as a direct result of a visitor's interaction with a website.

Unique Visitors: Provides an unduplicated count of all individually identified machines that made a visit to a selected domain during a given analysis period.

Time Spent: Measured in seconds, the elapsed time between the first page request at a domain and the last page request at the same domain within a given visit."

Reach was used directly as a variable in the study (V1). Three other variables were obtained by forming ratios. Their definitions, in the words of NetScore ${ }^{\circledR}$, are:

Pages per Visitor (V2), "calculated by dividing the total number of page hits at a specific domain by the number of unique visitors to that domain during the analysis period".

Seconds per Visitor (V3), "calculated by dividing the sum of the elapsed time between the first page request at a domain and the last page request at the same domain across all visits by the number of unique visitors to the domain during the analysis period". 
Seconds per Page (V4), "calculated by dividing the sum of the elapsed time between the first page request at a domain and the last page request at the same domain across all visits by the number of visits to the domain during the analysis period".

Besides these three web metrics, other information was included in the data set. Variables 5 to 34 combine data obtained from NetScore ${ }^{\circledR}$ with information from the balance sheet and the profit and loss accounts. The particular accounting items used are: revenues, selling and marketing expenses, gross profit, cash flow, number of employees, total assets, total operating expenses, total liabilities, and R\&D expenses. See Table 2 for the complete list of variables and their definitions and descriptive statistical information about the variables used in this study.

\begin{tabular}{|c|c|c|c|c|c|c|c|}
\hline & Average & Median & Minimum & Maximum & Std Dev & Skewness & Kurtosis \\
\hline V1 Reach & 8.18 & 5.35 & 0.30 & 58.60 & 10.19 & 3.35 & 15.08 \\
\hline V2 Page Hits per Visitor & 46.95 & 25.51 & 5.58 & 531.60 & 89.83 & 4.74 & 23.66 \\
\hline V3 Avg. time spent per visitor & 1159.35 & 677.00 & 122.00 & 9349.00 & 1865.27 & 3.80 & 14.48 \\
\hline V4 Avg. time spent per page & 26.43 & 22.00 & 14.00 & 69.00 & 12.59 & 1.55 & 2.41 \\
\hline V5 Reach/Number of Employees & 2.69 & 1.78 & 0.09 & 11.56 & 2.85 & 1.85 & 3.14 \\
\hline V6 Revenues/Reach & 213.12 & 70.87 & 3.28 & 1932.89 & 433.17 & 3.10 & 9.23 \\
\hline V7 Reach/Selling \& Marketing Expenses & 0.02 & 0.01 & 0.00 & 0.05 & 0.01 & 1.15 & 0.66 \\
\hline V8 Gross Profit/Reach & -137.83 & -93.80 & -1008.97 & 429.45 & 220.33 & -1.49 & 6.17 \\
\hline V9 Reach/Cash Flow & 0.03 & 0.02 & 0.00 & 0.11 & 0.03 & 1.73 & 2.01 \\
\hline V10 Reach/Total Assets & 0.01 & 0.00 & 0.00 & 0.05 & 0.01 & 2.48 & 6.33 \\
\hline V11 Reach/R\&D Expenses & 0.11 & 0.06 & 0.00 & 0.57 & 0.13 & 2.22 & 4.84 \\
\hline V12 Reach/Total Operating Expenses & 0.01 & 0.01 & 0.00 & 0.03 & 0.01 & 1.17 & 0.21 \\
\hline V13 Reach/Total Liabilities & 0.03 & 0.02 & 0.00 & 0.23 & 0.04 & 2.82 & 10.61 \\
\hline V14 Unique Visitors/Number of Employees & 18.20 & 12.05 & 0.54 & 78.16 & 19.22 & 1.85 & 3.15 \\
\hline V15 Revenues /Unique Visitors & 32.06 & 10.26 & 0.49 & 291.29 & 65.40 & 3.07 & 8.97 \\
\hline V16 Unique Visitors/Selling \& Marketing & 0.12 & 0.10 & 0.01 & 0.37 & 0.09 & 1.14 & 0.64 \\
\hline V17 Gross Profit/Unique Visitors & -20.65 & -13.68 & -161.87 & 63.68 & 33.87 & -1.78 & 7.62 \\
\hline V18 Unique Visitors/Cash Flow & 0.18 & 0.11 & 0.01 & 0.76 & 0.22 & 1.73 & 2.03 \\
\hline V19 Unique Visitors/Total Assets & 0.05 & 0.02 & 0.00 & 0.36 & 0.08 & 2.46 & 6.17 \\
\hline V20 Unique Visitors/R\&D Expenses & 0.75 & 0.37 & 0.03 & 3.86 & 0.91 & 2.23 & 4.90 \\
\hline V21 Unique Visitors/Total Operating Exp. & 0.07 & 0.05 & 0.00 & 0.21 & 0.06 & 1.16 & 0.20 \\
\hline V22 Unique Visitors/Total Liabilities & 0.23 & 0.12 & 0.00 & 1.57 & 0.29 & 2.80 & 10.51 \\
\hline V23 Page Hits/Number of Employees & 747.22 & 368.05 & 9.78 & 6154.63 & 1305.98 & 3.40 & 11.94 \\
\hline V24 Revenues/Page Hits & 1.07 & 0.32 & 0.03 & 10.36 & 2.02 & 3.36 & 12.33 \\
\hline
\end{tabular}




\begin{tabular}{l|lllllll}
\hline V25 Page Hits/Selling \& Marketing & 6.46 & 2.50 & 0.14 & 77.51 & 14.14 & 4.24 & 18.76 \\
V26 Gross Profit/Page Hits & -1.22 & -0.51 & -8.87 & 1.76 & 2.23 & -2.48 & 6.12 \\
V27 Page Hits/Cash Flow & 6.83 & 2.34 & 0.14 & 41.14 & 10.07 & 2.21 & 4.39 \\
V28 Page Hits/Total Assets & 1.96 & 0.66 & 0.02 & 17.01 & 3.36 & 2.92 & 9.94 \\
V29 Page Hits/R\&D Expenses & 33.65 & 12.05 & 0.45 & 300.21 & 62.01 & 3.16 & 10.51 \\
V30 Page Hits/Total Operating Expenses & 3.51 & 1.23 & 0.09 & 43.75 & 7.79 & 4.34 & 20.10 \\
V31 Page Hits/Total Liabilities & 8.54 & 3.18 & 0.08 & 64.47 & 14.37 & 2.99 & 8.83 \\
V32 Revenues/Hours & 151.31 & 42.39 & 2.39 & 1126.13 & 243.27 & 2.62 & 7.19 \\
V33 Gross Profit/Hours & -184.40 & -93.50 & -1925.19 & 224.36 & 367.75 & -3.41 & 13.69 \\
V34 Hours/Total Operating Expenses & 0.02 & 0.01 & 0.00 & 0.21 & 0.05 & 3.40 & 11.66 \\
\hline
\end{tabular}

Table 2. Descriptive statistical information on the variables used in this study

In this paper, web metrics are treated as the outputs of a dot com company, since all these firms aim at making an impact on the Internet. In order to make such an impact, dot coms have liabilities, employ staff, engage in research, spend on marketing, etc. As a result of such way of operating, they obtain revenues and profit. Ratios 5 to 34 are, in a way, measuring productivity and efficiency in the sense that they relate accounting information to web impact. However, what dot coms aim to achieve depends on the type of activity in which they engage. For example, an internet portal, whose main source of income is publicity (banners) is crucially interested in page hits; while a community services site would be more interested in obtaining many unique visitors, as its popularity would bring with it advertising sponsorship or membership fees. Attracting visitors to its web site is also important for an e-tailer, since the higher their number, the higher the number of potential customers. But attracting visitors is of little relevance if visitors do not become customers. Thus, these ratios depend on the particular business niche in which the dot com company operates, and may reflect strategic differences. Exploring whether such differences exist is another objective of this study.

Section 3 will further elaborate on these issues by using variables 1 to 34 in order to find visualizations of the data set that will reveal intangible asset issues. Such visualizations will take the form of statistical maps.

A further variable (V35), which attempts to measure DEA efficiency, is also used. The rationale for such variable and the way in which it was calculated is the subject of the next subsection. 


\subsection{Efficiency measurement}

Productive efficiency can be assumed to measure an internal intangible asset associated with management. An attempt was made to measure production efficiency by means of Data Envelopment Analysis (DEA). A firm is a production unit that uses inputs in order to generate outputs. It is possible to use too many inputs to produce a given quantity of output, or to generate less output than possible for a given quantity of input. If, given the amounts of inputs used, it cannot be demonstrated that an increase in output is possible, it is said that the firm is efficient and that it is operating on the production efficiency frontier; Fare et al. (1994).

The traditional way of studying efficiency is through production function analysis but, in recent times, DEA has proven to be invaluable as an approach for the study of productive efficiency. Introductions to DEA can be found in Land (1991), and Norman and Stocker (1991).

DEA has proven to be particularly valuable in the assessment of performance when outputs other than profit are involved; this is why it is quickly becoming an important analysis tool in public sector management; Ganley and Cubbin (1992). Efficiency, as calculated through DEA is often interpreted as a measure of quality in the provision of services, or managerial efficiency in not-for-profit organizations. It is an ideal tool to measure the achievement of intangible objectives.

A dot com company employs staff, takes loans, spends money, and acquires assets (inputs) in order to have an impact on the web. This impact is reflected in web metrics (outputs). Of course, this is a partial view of the complex world of Internet companies.

For each company, a DEA measure of efficiency is obtained by treating total operating expenses, total assets, number of employees, and total liabilities as inputs in the DEA model. Reach, unique visitors, page hits, and time spent were treated as outputs. Thus, efficiency is understood in this paper as the optimal use of resources in order to make an impact in the Internet. Financial variables, such as revenues or profits, were not treated as outputs in the model. Obviously, in the long run the aim of a dot.com firm is to make profits. But most firms included in this study are very young and are more concerned about establishing their presence 
than make a profit. In fact, most make losses (35 out of the 40). They might be sacrificing today's butter to tomorrow's jam. We concluded that, on the basis of the data used, dot.com firms could not be assessed on the grounds of profitability, but we could examine their relative efficiency in the DEA sense. Our DEA formulation tries to measure the efficiency in the achievement of the objective of establishing their presence in the market.

The model asks the question if the inputs used by a particular firm would have generated more output if made available to the rest of the firms in the sample. If it cannot be demonstrated that something would be gained by closing the firm and distributing its inputs through the system, the firm is deemed to be efficient. Firms can be efficient in a variety of ways. They can be role models that other firms can take as an example of behaviour: comparators. But they can also be efficient because their behaviour is so extreme that they cannot be compared to anything else; these are called self comparators. The model proposed by Charnes et al. (1978), also known as the CCR model, was estimated. The last column of Table 1 shows DEA efficiency estimates for each company. The philosophy of DEA is based on multiple comparisons.

The efficiency measure takes on values between $0 \%$ and $100 \%$. Efficient firms have an efficiency rating of $100 \%$. The firms that were found to be $100 \%$ efficient are: ASKJ (19), EBAY (6), LFMN (4), ONHN (5), TVLY (2), UPRO (39) and YHOO (2). The numbers in brackets refer to the number of times this firm has been taken to be a comparator for an inefficient firm. This is a measure of up to what point they can be treated as benchmarks. The most common benchmarks are UPRO and ASKJ. ADBL, AMZN, EGGS, FATB, NBCI, and MCNS show the lowest efficiency values.

A question that may be asked is: up to what point firms that are efficient at achieving an impact in the net are also profitable firms?. To address this issue, Pearson's correlation coefficient between financial profitability and efficiency was calculated and found to take the value 0.175 . This was not significantly different from zero, indicating that, at least at this stage in the life of dot.com firms, profitability and efficiency (as measured here) are two independent concepts.

This DEA relative efficiency could be interpreted as the intangible asset: "efficiency in achieving an impact in the Internet". Firms could be ranked in 
order of comparative efficiency but, what would explain this ranking?. To attempt to answer this question, DEA results are put in their context and visualised using multivariate statistics in the next section. Visualisation will reveal other intangible assets.

\section{INTANGIBLE ASSET IDENTIFICATION AND MEASUREMENT WITH MDS AND PF}

The approach followed will be to compare firms in order to see up to what point they are similar or different on the basis of the first 34 variables described above. Measures of dissimilarity will be obtained between pairs of companies, and statistical maps will be produced from such measures. These statistical maps will reflect the strategic profiles of behaviour, and will be interpreted using appropriate statistical tools.

This section will be divided into several subsections. First, a summary description of scaling models will be given. Results from multidimensional scaling will form the second subsection. Interpretation will form the next subsection.

\subsection{The model}

We have chosen to use scaling models because they visualise the main characteristics in the data so that any relationship that may exist in the data is made explicit and revealed in a statistical map. Scaling models have traditionally been applied in areas where relationships between entities are based on qualitative information, or on counts. This happens in Psychology, Sociology, Politics, and even History. Applications in the analysis of management policy and in Accounting and Finance are: Green and Maheshwary (1969), Moriarity and Barron (1976), Belkaoui and Cousineau (1977), Rockness and Nikolai (1977), Frank (1979), Libby (1979), Belkaoui (1980), Brown (1981), Emery et al. (1982), Bailey et al. (1983), Mar Molinero and Ezzamel (1991), Mar Molinero et al (1996), Mar Molinero and Serrano Cinca (2001), and Serrano Cinca et al. (2002 and 2003). Scaling models have also been applied to strategic group analysis; Day et al. (1987), and Hodgkinson et al. (1996).

The main technique used in the analysis is Ordinal Multidimensional Scaling (MDS); see Kruskal (1964) or Kruskal and Wish (1978). A brief explanation of 
the rationale of MDS follows. Given the position of two points in the space, it is easy to calculate the distance that separates them. MDS works in the opposite direction. We start from a measure of how distant two entities are: a measure of dissimilarity. The entities are then positioned in the space in such a way that if the value of the dissimilarity measure is small they are located next to each other, and if the measure of dissimilarity is high they are located far apart. In general, and this is the case in the present paper, the measure of dissimilarity is derived from a data set. There are various tools that measure the quality of the representation, although the most common measure of fit is a statistic, stress, very much like $\mathrm{R}^{2}$ in regression. Low levels of the stress statistic are associated with a good description of the model, while high values of the stress are associated with a poor representation. Stress is normalised so that it takes the value zero for perfect fit or 1 for a model that has nothing to contribute to the structure of the data. Another way of calculating the quality of fit of an MDS representation (configuration) is to run a regression between the dissimilarities (input to the model) and the distances calculated from the position of the points in the space, and to report the value of $\mathrm{R}^{2}$ in this regression. In this last case, $\mathrm{R}^{2}$ equal to one is associated with perfect fit.

In this particular case, the measure of dissimilarity will reflect how similar or different are two dot com companies on the basis of the 34 variables used to describe each one of them. A matrix is created which contains companies as rows and columns, the value in the cell being the dissimilarity measure between the company at the beginning of the row and the top of the column. This matrix is symmetric; i.e., the dissimilarity between company $i$ and company $j$ is assumed to be the same as the dissimilarity between company $j$ and company $i$. MDS plots companies as a map in the space (configuration) in such a way that if the variables that describe two companies are similar, the companies are plotted next to each other in the space.

Implementing scaling models is a process of several stages. In this case, variables are measured in different units. If the variables that enter the algorithm are measured in their original units, the importance that each has in the final result depends on the units chosen, something that makes the results data dependent. To avoid this problem, variables were standardized to zero mean and unit variance. 
Next, dissimilarities between dot com companies were calculated by taking the Euclidean distance between standardized variables. If a variable was not available for a company, the measure of dissimilarity was based only on the remaining variables. In the common case of two-way data there is a parallel between Principal Components Analysis (PCA) and Scaling methods based on the metric of Euclidean distance between standardized data (Chatfield and Collins, 1980).

PCA is a standard technique in multivariate statistical analysis. It is a data reduction technique. When many variables are associated with a particular entity, such as a dot com company, it is suspected that some of them will be measuring the same characteristic of the company. It may be that several variables may, in fact, be indicators of a characteristic of the company that cannot be measured. How many independent characteristics are necessary to describe a company, what variables are associated with this characteristic, and up to what point a particular variable contributes to the explanation of the characteristic, are inferred from the solution of the PCA exercise. For an introduction to PCA see Chatfield and Collins (1980). There is much in common between MDS and PCA, but, in this particular case, MDS has a crucial advantage over PCA: PCA plots companies only if full information is available for the company, while MDS is robust to missing data. Thus, if maps had been created with PCA, they would have contained only 35 points, since the value of at least one variable was missing for 5 firms: ALOY, AMEN, CNET, EGGS, and TVLY. Three of the 34 ratios could not be calculated for these five firms: V11, V20, and V29 in the case of ALOY, AMEN, CNET, and EGGS; V9, V18, and V27 for TVLY. This loss of information would have required deleting the firms from the data set if other techniques had been used. In our case MDS made it possible to keep these firms in the analysis.

A common problem when working with company data is the presence of outliers, or extreme cases. It is usual practice to use some statistical test to identify them, and then remove them; the issues relating to outlier detection and removal in management data have been discussed by Ezzamel and Mar Molinero (1990). Scaling models are robust to the presence of outliers, and there is no need to remove them, but if these are left in the data, the resulting statistical maps are more cluttered and less attractive to view. Nevertheless, outliers can be important, as they may reveal important features, which would not have been observed 
otherwise. The option taken here was to identify discordant companies, leave them in the data set, estimate the model, observe the position of such companies in the common map, study their special features and assess if they are related to some distinctive strategic behaviour, and, finally, explore the bulk of the companies in order to reveal the main features of the generality of the data.

\begin{tabular}{l|l}
\hline Ticker & Variable \\
\hline ADBL & v26 v33 \\
ALOY & v11 v20 v29 \\
AMEN & v11 v20 v29 \\
CNET & v11 v20 v29 \\
EBAY & v2 v3 v23 v25 v29 v30 v31 v34 \\
EGGS & v6 v11 v15 v20 v29 \\
FATB & v8 v17 v24 v26 \\
LFMN & v5 v11 v14 v20 \\
ONHN & v5 v14 \\
SPLN & v11 v20 \\
TVLY & v9 v10 v18 v19 v27 v28 \\
UPRO & v13 v22 v31 \\
WOMN & v3 \\
YHOO & v1 v3 v23 v25 v27 v34 \\
\hline
\end{tabular}

Table 3. Outliers. Variables involved.

Extreme observation identification was based on Tchebychev's inequality, as in Ezzamel and Mar Molinero (1990). For each variable, the companies that reported a standardized value greater than three were identified as extreme cases. Table 3 shows the companies identified in this way and the ratios involved.

\subsection{Multidimensional scaling analysis}

We used Principal Components Analysis (PCA) in order to assess the dimensionality of the data. This was done by treating dissimilarity matrices as correlation matrices, and observing how many eigenvalues are greater than 1.0, as it is common practice with this technique. Six eigenvalues were found to have values over 1.0, and the analysis was carried out in a six dimensional space. The percentage of the variance explained by the six eigenvectors was $90.38 \%$. The first component was found to explain $42.769 \%$ of the variance. The second component added a further $22.236 \%$ of the variance. The third one accounted for 
$10.798 \%$ of the variance. The remaining components added only about 5\%. It is clear that the first component is also going to be of crucial importance in the explanation of the data, with some additional contribution from the second component. A graphical representation on two dimensions would, therefore, explain $65 \%$ of the variance, and would provide a good picture of the world of dot com companies.

An ordinal MDS analysis was carried out in a six dimensional space. A value of 0.0358 was found for Stress 1. This value is described in the range "good" (0.05) to "excellent" (0.025) in Kruskal's (1964) verbal classification, and suggests that the configurations contain a story worth listening to. Configurations are a set of points on a six dimensional space. It has long been known -see, for example, Thom (1989)- that even if many variables, or dimensions in our case, are involved in a model, only a small number of them may be relevant in a particular study. This was also found in this case. For this reason, rather than give all the projections on to pairs of dimensions, only projection on Dimension 1 and Dimension 2 is shown here. This can be seen in Figure 1.

As was expected, given the presence of extreme observations, most companies in Figure 1 appear cluttered in a small area of the map. A few companies are clearly visible. Normally, meaning is associated with the dimensions, and this is a subject that will be pursued below, so that if a company appears far from the crowd in a particular dimension, it can be interpreted as having a high value of the characteristic measured by that dimension.

It is to be noticed that UPRO, ASKJ, EBAY, YHOO, ONHN, LFMN and, TVLY are associated with large positive values of Dimension 1. DEA associates them with $100 \%$ efficiency. They are all located on the right hand side of Figure 1. The firms that are located on the left hand side of Dimension 1 have lower DEA efficiency values. Examples are: ADBL, AMZN, EGGS, FATB, NBCI, and MCNS. It appears that the higher the coordinate of the firm in Dimension 1, the higher the value of the intangible "efficiency in achieving an impact in the Internet". A simple calculation of Pearson's correlation coefficient between the coordinate in Dimension 1 and DEA efficiency returns 0.945 , a very high value. It appears that the position of a company on Dimension 1 is clearly associated with an efficiency ranking. This ranking is clearly revealed by looking at the figure. An 
interesting aspect of Figure 1 is that e-tailers (ADBL, AMZN, EGGS, and FATB) are abundant on the left hand side of the figure. It would appear that these firms are not DEA efficient according to our model. But, why should they be?. The DEA model measures efficiency in terms of the achievement of an impact in the Internet while this may not be a priority for them. Perhaps a better model for them would include other web metrics such as "purchase rate", or percentage of unique visitors who make a purchase. However, this information was not available.

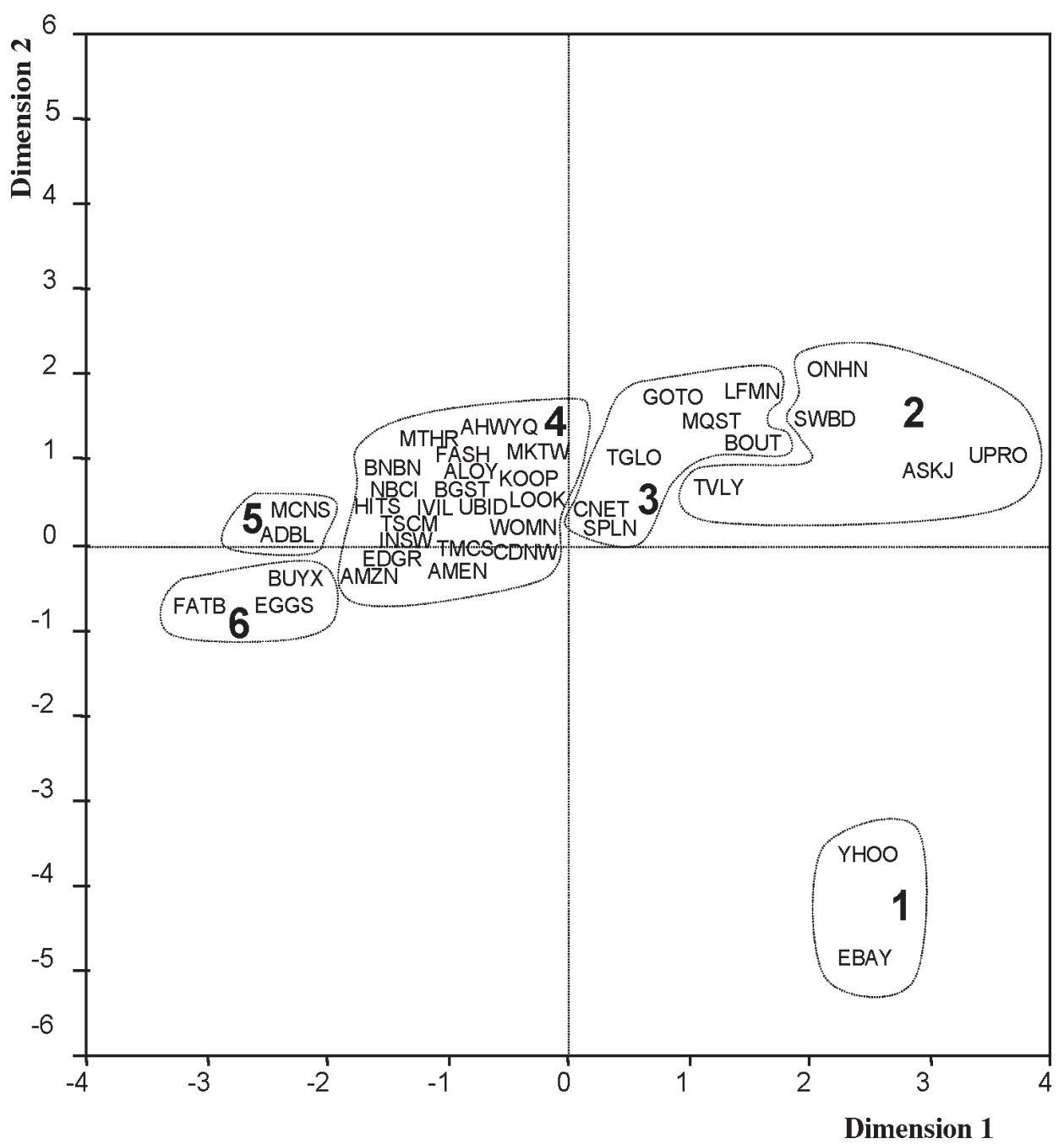

Figure 1. Multidimensional scaling and cluster analysis results. Projection on Dimension 1 and Dimension 2 
Companies associated with large positive measurements in Dimension 2 are EBAY and YHOO. To attach meaning to the second dimension, and indeed to all the remaining dimensions, it is necessary to use other formal techniques such as property fitting and hierarchical cluster analysis. This will be done in the next section.

\subsection{Interpretation of results with Property Fitting (PF) and Hierarchical Cluster Analysis (HCA)}

In each dimension of the configuration, a number of companies have shown up as being distinctive. In order to assess what is special about these companies meaning has to be attached to the axes. A regression-based approach, property fitting (PF), was used to interpret the results (Schiffman et al. 1981).

The idea behind PF analysis is as follows. If a characteristic of the data is associated with its position in the map, it can be conjectured that there is a relationship between the position on the map, as measured by the coordinates of the point, and the characteristic under investigation (property). Thus, the value that the property takes is a function of the coordinates of the point. As a first approximation this relationship is assumed to be a linear one, and a regression model is built in which the dependent variable is the value of the property and each coordinate is an explanatory variable. The extent to which the property is or is not well explained by the location of the point is measured by the coefficient of determination, $\mathrm{R}^{2}$.

In summary, we consider the possibility of a relationship between dimensions and variables. In formal terms we can write:

$$
\mathrm{V}_{\mathrm{k}}^{\mathrm{m}}=\mathrm{f}\left(\mathrm{D} 1_{\mathrm{k}}, \mathrm{D} 2_{\mathrm{k}}, \mathrm{D} 3_{\mathrm{k}}, \mathrm{D} 4_{\mathrm{k}}, \mathrm{D} 4_{\mathrm{k}}, \mathrm{D} 6_{\mathrm{k}}\right)+\mathrm{e}_{\mathrm{k}}^{\mathrm{m}}
$$

where $\mathrm{V}_{\mathrm{k}}^{\mathrm{m}}$ is the value obtained by company $\mathrm{k}$ under variable $\mathrm{m} ;{ }^{\mathrm{D}} 1_{\mathrm{k}}$ is the value of the coordinate on the first dimension for company $\mathrm{k}$; and so on. ${ }^{\mathrm{m}} \mathrm{k}$. is an error term.

In the absence of any other information, we assume function $\mathrm{f}$ to be linear.

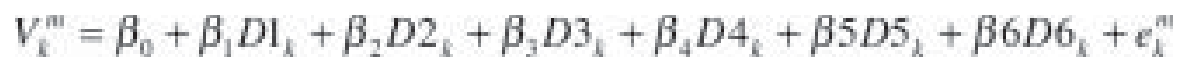


This is just a regression equation where the $\beta i$ are the unknowns. It is possible to represent the results of the regression as a directional vector through the map, in such a way that the value of the property grows in the direction of the vector.

Variables were taken one at a time and treated as properties. The 34 variables on which the configuration was estimated (the first four being web metrics and the remaining 30 being ratios involving web metrics and financial information) were first treated as properties. This is known as Internal Analysis. Next, the DEA efficiency measure was treated as a property. This use, at the interpretation stage, of variables that were not involved in model building is known as External Analysis.

Statistical results for PF analysis are shown in Table 4. Not all the variables on which PF analysis was performed have been plotted as directional vectors in Figure 2. Only those for which $\mathrm{R}^{2}$ was greater than $60 \%$ are shown. Directional vectors $\gamma i$, are proportional to $\beta i$ and are shown in Figure 2. This table includes the 34 variables involved in internal analysis, and the results of DEA. We could say that Figure 2 contains the compass that will help us to navigate through Figure 1.

\begin{tabular}{|c|c|c|c|c|c|c|c|c|}
\hline & & & Direction & osines & & & 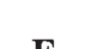 & Adj. \\
\hline & $\gamma_{1}$ & $\gamma_{2}$ & $\gamma_{3}$ & $\gamma_{4}$ & $\gamma_{5}$ & $\gamma_{6}$ & & \\
\hline & 0.64 & -0.74 & 0.12 & 0.15 & 0.11 & 0.00 & 807 & 0551 \\
\hline$V_{1}$ & $(5.486)^{* *}$ & $(-4.677)^{* *}$ & $(0.553)$ & $(0.536)$ & $(0.369)$ & $(-1.489)$ & 8.91 & 0.551 \\
\hline & 0.29 & -0.93 & 0.10 & 0.01 & 0.06 & 0.18 & & 7 \\
\hline$V_{2}$ & $(9.331)^{* *}$ & $(-22.087)^{* *}$ & $(1.816)$ & $(0.177)$ & $(0.768)$ & (1.999) & & I \\
\hline & 0.32 & -0.92 & 0.12 & -0.04 & 0.00 & -0.19 & & \\
\hline$V$ & $(14.154)^{* *}$ & $(-30.420)^{* *}$ & $(2.927)^{*}$ & $(-0.787)$ & $(-1.549)$ & $(-2.979)^{*}$ & & 7 \\
\hline & -0.01 & 0.01 & 0.01 & -0.14 & -0.50 & -0.86 & & \\
\hline & $(-0.167)$ & $(0.136)$ & $(0.147)$ & $(-1.159)$ & $(-3.926)^{* *}$ & $(-5.785)^{* *}$ & 8.7 &. .542 \\
\hline & 0.63 & 0.45 & -0.45 & 0.10 & 0.00 & 0.44 & & \\
\hline & $(10.367)^{* *}$ & $(5.476)^{* *}$ & $(-4.064)^{* *}$ & $(0.696)$ & $(-0.030)$ & $(2.561)^{*}$ & & 0.800 \\
\hline & -0.25 & -0.20 & -0.69 & 0.41 & 0.36 & -0.36 & & \\
\hline & $(-12.395)^{* *}$ & $(-7.522)^{* *}$ & $(-18.799)^{* *}$ & $(8.802)^{* *}$ & $(7.357)^{* *}$ & $(-6.195)^{* *}$ & & .949 \\
\hline & 0.78 & 0.31 & -0.02 & 0.07 & -0.23 & -0.50 & & \\
\hline $\mathbf{V}$ & $(12.851)^{* *}$ & $(3.808)^{* *}$ & $(-0.172)$ & $(0.480)$ & $(-1.519)$ & $(-2.871)^{*}$ & 3 & .824 \\
\hline $\mathrm{T}$ & 0.43 & 0.13 & 0.74 & 0.23 & 0.43 & -0.13 & 3888 & 854 \\
\hline & $(10.273)^{* *}$ & (2.238) & $(9.621)^{* *}$ & $(2.380)$ & $(4.154)^{* *}$ & $(-1.086)$ & 88.88 & 0.854 \\
\hline & 0.47 & 0.33 & -0.41 & -0.50 & 0.50 & 0.08 & & ? \\
\hline ( & $(11.950)^{* *}$ & $(6.289)^{* *}$ & $(-5.685)^{* *}$ & $(-4.809)^{* *}$ & $(4.519)^{* *}$ & $(0.704)$ & 34 & .852 \\
\hline & 0.41 & 0.29 & -0.47 & -0.56 & 0.44 & 0.14 & & \\
\hline$V_{1}$ & $(12.474)^{* *}$ & $(6.592)^{* * *}$ & $(-7.747)^{* *}$ & $(-7.294)^{* *}$ & $(5.341)^{* *}$ & $(1.498)$ & 3 & 900 \\
\hline & 0.28 & 0.17 & -0.16 & 0.80 & -0.07 & 0.48 & & \\
\hline & $(10.144)^{* *}$ & $(4.503)^{* *}$ & $(-2.842)^{*}$ & $(11.494)^{* *}$ & $(-1.014)$ & $(6.110)^{* *}$ & & \\
\hline
\end{tabular}




\begin{tabular}{|c|c|c|c|c|c|c|c|c|}
\hline$V_{12}$ & $\begin{array}{c}0.85 \\
(15.830)^{* *}\end{array}$ & $\begin{array}{c}0.39 \\
(5.392)^{* *}\end{array}$ & $\begin{array}{c}-0.24 \\
(-2.422)\end{array}$ & $\begin{array}{c}0.17 \\
(1.366)\end{array}$ & $\begin{array}{c}-0.14 \\
(-1.030)\end{array}$ & $\begin{array}{c}-0.17 \\
(-1.092)\end{array}$ & 48.04 & 0.879 \\
\hline$V_{13}$ & $\begin{array}{c}0.41 \\
(10.448)^{* *}\end{array}$ & $\begin{array}{c}0.31 \\
(5.790)^{* *}\end{array}$ & $\begin{array}{c}-0.19 \\
(-2.575)^{*}\end{array}$ & $\begin{array}{c}0.17 \\
(1.804)\end{array}$ & $\begin{array}{c}-0.80 \\
(-8.180)^{* *}\end{array}$ & $\begin{array}{c}-0.19 \\
(-1.647)\end{array}$ & 36.79 & 0.846 \\
\hline 14 & $\begin{array}{c}0.63 \\
(10.336)^{* *}\end{array}$ & $\begin{array}{c}0.45 \\
(5.480)^{* *}\end{array}$ & $\begin{array}{c}-0.45 \\
(-4.024)^{* *}\end{array}$ & $\begin{array}{c}0.10 \\
(0.704)\end{array}$ & $\begin{array}{c}-0.01 \\
(-0.042)\end{array}$ & $\begin{array}{c}0.45 \\
(2.556)^{*}\end{array}$ & 26.81 & 0.799 \\
\hline$V_{1}$ & $\begin{array}{c}-0.25 \\
(-13.552)^{* *}\end{array}$ & $\begin{array}{c}-0.20 \\
(-8.189)^{* *}\end{array}$ & $\begin{array}{c}-0.70 \\
(-20.653)^{* *}\end{array}$ & $\begin{array}{c}0.41 \\
(9.412)^{* *}\end{array}$ & $\begin{array}{c}0.35 \\
(7.576)^{* *}\end{array}$ & $\begin{array}{c}-0.36 \\
(-6.745)^{* *}\end{array}$ & 144.78 & 0.957 \\
\hline$V_{16}$ & $\begin{array}{c}0.77 \\
(12.753)^{* *}\end{array}$ & $\begin{array}{c}0.31 \\
(3.816)^{* *}\end{array}$ & $\begin{array}{c}-0.01 \\
(-0.100)\end{array}$ & $\begin{array}{c}0.06 \\
(0.457)\end{array}$ & $\begin{array}{c}-0.23 \\
(-1.517) \\
\end{array}$ & $\begin{array}{c}-0.50 \\
(-2.845)^{*}\end{array}$ & 30.89 & 0.821 \\
\hline$V_{17}$ & $\begin{array}{c}0.42 \\
(10.393)^{* *}\end{array}$ & $\begin{array}{c}0.13 \\
(2.363)\end{array}$ & $\begin{array}{c}0.75 \\
(10.056)^{* *}\end{array}$ & $\begin{array}{c}0.22 \\
(2.330)\end{array}$ & $\begin{array}{c}0.44 \\
(4.331)^{* *}\end{array}$ & $\begin{array}{c}0.00 \\
(-0.920)\end{array}$ & 41.14 & 0.861 \\
\hline$V_{1}$ & $\begin{array}{c}0.47 \\
(12.092)^{* *}\end{array}$ & $\begin{array}{c}0.33 \\
(6.376)^{* *}\end{array}$ & $\begin{array}{c}-0.41 \\
(-5.736)^{* *}\end{array}$ & $\begin{array}{c}-0.50 \\
(-4.897)^{* *}\end{array}$ & $\begin{array}{c}0.50 \\
(4.595)^{* *}\end{array}$ & $\begin{array}{c}0.08 \\
(0.699)\end{array}$ & 38.28 & 0.855 \\
\hline $\mathbf{V}_{1}$ & $\begin{array}{c}0.41 \\
(12.577)^{* *}\end{array}$ & $\begin{array}{c}0.30 \\
(6.676)^{* *}\end{array}$ & $\begin{array}{c}-0.47 \\
(-7.761)^{* *}\end{array}$ & $\begin{array}{c}-0.56 \\
(-7.339)^{* *}\end{array}$ & $\begin{array}{c}0.44 \\
(5.356)^{* *}\end{array}$ & $\begin{array}{c}0.14 \\
(1.487)\end{array}$ & 60.06 & 0.901 \\
\hline$V_{20}$ & $\begin{array}{c}0.28 \\
(10.109)^{* *}\end{array}$ & $\begin{array}{c}0.16 \\
(4.501)^{* *}\end{array}$ & $\begin{array}{c}-0.16 \\
(-2.803)^{*}\end{array}$ & $\begin{array}{c}0.80 \\
(11.508)^{* *}\end{array}$ & $\begin{array}{c}-0.07 \\
(-1.000)\end{array}$ & $\begin{array}{c}0.48 \\
(6.139)^{* *}\end{array}$ & 54.97 & 0.902 \\
\hline $\mathbf{V}$ & $\begin{array}{c}0.85 \\
(15.664)^{* *}\end{array}$ & $\begin{array}{c}0.39 \\
(5.373)^{* *}\end{array}$ & $\begin{array}{c}-0.23 \\
(-2.327)\end{array}$ & $\begin{array}{c}0.17 \\
(1.339)\end{array}$ & $\begin{array}{c}-0.14 \\
(-1.025) \\
\end{array}$ & $\begin{array}{c}-0.17 \\
(-1.087)\end{array}$ & 47.05 & 0.876 \\
\hline $\mathbf{V}_{22}$ & $\begin{array}{c}0.41 \\
(10.413)^{* *}\end{array}$ & $\begin{array}{c}0.31 \\
(5.803)^{* *}\end{array}$ & $\begin{array}{c}-0.18 \\
(-2.521)^{*}\end{array}$ & $\begin{array}{c}0.16 \\
(1.784)\end{array}$ & $\begin{array}{c}-0.80 \\
(-8.171) * *\end{array}$ & $\begin{array}{c}-0.19 \\
(-1.644)\end{array}$ & 36.61 & 0.846 \\
\hline $\mathbf{V}_{2}$ & $\begin{array}{c}0.54 \\
(24.674)^{* *}\end{array}$ & $\begin{array}{c}-0.81 \\
(-27.599)^{* *}\end{array}$ & $\begin{array}{l}-0.05 \\
(-1.179)\end{array}$ & $\begin{array}{c}-0.17 \\
(-3.349)^{*}\end{array}$ & $\begin{array}{c}0.04 \\
(0.717)\end{array}$ & $\begin{array}{c}0.12 \\
(1.883)\end{array}$ & 231.27 & 0.973 \\
\hline $\mathbf{V}_{24}$ & $\begin{array}{c}-0.35 \\
(-11.302)^{* *}\end{array}$ & $\begin{array}{c}-0.18 \\
(-4.381)^{* *}\end{array}$ & $\begin{array}{c}-0.82 \\
(-14.518)^{* *}\end{array}$ & $\begin{array}{c}0.23 \\
(3.163)^{*}\end{array}$ & $\begin{array}{c}0.00 \\
(-0.047) \\
\end{array}$ & $\begin{array}{c}-0.35 \\
(-3.897)^{* *}\end{array}$ & 66.72 & 0.910 \\
\hline $\mathbf{V}_{25}$ & $\begin{array}{c}0.43 \\
(18.122)^{* *}\end{array}$ & $\begin{array}{c}-0.89 \\
(-27.901)^{* *}\end{array}$ & $\begin{array}{c}0.11 \\
(2.600)^{*}\end{array}$ & $\begin{array}{c}-0.05 \\
(-0.954)\end{array}$ & $\begin{array}{c}-0.06 \\
(-0.974)\end{array}$ & $\begin{array}{c}0.11 \\
(1.586)\end{array}$ & 186.45 & 0.966 \\
\hline $\mathbf{V}_{26}$ & $\begin{array}{c}0.30 \\
(9.419)^{* *}\end{array}$ & $\begin{array}{c}0.04 \\
(0.998)\end{array}$ & $\begin{array}{c}0.35 \\
(6.042)^{* *}\end{array}$ & $\begin{array}{c}0.44 \\
(5.810)^{* *}\end{array}$ & $\begin{array}{c}0.62 \\
(7.791)^{* *}\end{array}$ & $\begin{array}{c}-0.46 \\
(-4.952)^{* *}\end{array}$ & 39.73 & 0.856 \\
\hline $\mathbf{V}_{27}$ & $\begin{array}{c}0.58 \\
(14.200)^{*}\end{array}$ & $\begin{array}{c}-0.49 \\
(-9.115)^{* *}\end{array}$ & $\begin{array}{c}-0.23 \\
(-3.003)^{*}\end{array}$ & $\begin{array}{c}-0.45 \\
(-4.180)^{* *}\end{array}$ & $\begin{array}{c}0.41 \\
(3.591)^{* *}\end{array}$ & $\begin{array}{c}0.01 \\
(0.120)\end{array}$ & 50.83 & 0.887 \\
\hline $\mathbf{V}_{28}$ & $\begin{array}{c}0.43 \\
(9.038)^{* *}\end{array}$ & $\begin{array}{c}-0.21 \\
(-3.317)^{*}\end{array}$ & $\begin{array}{c}-0.34 \\
(-3.881)^{* *}\end{array}$ & $\begin{array}{c}-0.63 \\
(-5.672)^{* *}\end{array}$ & $\begin{array}{c}0.49 \\
(4.150)^{* *}\end{array}$ & $\begin{array}{c}0.10 \\
(0.737)\end{array}$ & 27.19 & 0.801 \\
\hline$V_{29}$ & $\begin{array}{c}0.37 \\
(8.469)^{* *}\end{array}$ & $\begin{array}{c}-0.65 \\
(-11.274)^{* *}\end{array}$ & $\begin{array}{c}0.04 \\
(0.408)\end{array}$ & $\begin{array}{c}0.49 \\
(4.518)^{* *}\end{array}$ & $\begin{array}{c}-0.03 \\
(-0.319)\end{array}$ & $\begin{array}{c}0.43 \\
(3.449)^{*}\end{array}$ & 40.11 & 0.870 \\
\hline$V_{30}$ & $\begin{array}{c}0.45 \\
(16.021)^{* *}\end{array}$ & $\begin{array}{c}-0.87 \\
(-23.192)^{* *}\end{array}$ & $\begin{array}{c}0.08 \\
(1.475)\end{array}$ & $\begin{array}{c}-0.06 \\
(-0.869)\end{array}$ & $\begin{array}{c}-0.04 \\
(-0.642)\end{array}$ & $\begin{array}{c}0.16 \\
(1.973)\end{array}$ & 133.73 & 0.953 \\
\hline$V_{31}$ & $\begin{array}{c}0.52 \\
(13.420)^{* *}\end{array}$ & $\begin{array}{c}-0.54 \\
(-10.430)^{* *}\end{array}$ & $\begin{array}{c}-0.05 \\
(-0.757)\end{array}$ & $\begin{array}{c}0.03 \\
(0.326)\end{array}$ & $\begin{array}{c}-0.64 \\
(-6.700)^{* *}\end{array}$ & $\begin{array}{c}-0.12 \\
(-1.040)\end{array}$ & 55.85 & 0.894 \\
\hline $\mathbf{V}_{32}$ & $\begin{array}{c}-0.36 \\
(-10.303)^{* *}\end{array}$ & $\begin{array}{c}-0.17 \\
(-3.749)^{* *}\end{array}$ & $\begin{array}{c}-0.73 \\
(-11.504)^{* *}\end{array}$ & $\begin{array}{c}0.35 \\
(4.366)^{* *}\end{array}$ & $\begin{array}{c}0.36 \\
(4.186)^{* *}\end{array}$ & $\begin{array}{c}-0.24 \\
(-2.446)\end{array}$ & 49.26 & 0.881 \\
\hline $\mathbf{V}_{32}$ & $\begin{array}{c}0.34 \\
(6.583)^{* *}\end{array}$ & $\begin{array}{c}0.02 \\
(0.265)\end{array}$ & $\begin{array}{c}0.25 \\
(2.651)^{*}\end{array}$ & $\begin{array}{c}0.60 \\
(4.963)^{* *}\end{array}$ & $\begin{array}{c}0.68 \\
(5.370)^{* *}\end{array}$ & $\begin{array}{c}0.00 \\
(-6.570)^{* *}\end{array}$ & 23.03 & 0.772 \\
\hline $\mathbf{V}_{34}$ & $\begin{array}{c}0.51 \\
(36.867)^{* *}\end{array}$ & $\begin{array}{c}-0.81 \\
(-43.243)^{* *}\end{array}$ & $\begin{array}{c}0.06 \\
(2.321)\end{array}$ & $\begin{array}{c}-0.09 \\
(-2.923)^{*}\end{array}$ & $\begin{array}{c}-0.22 \\
(-6.312)^{* *}\end{array}$ & $\begin{array}{c}-0.17 \\
(-4.338)^{* *}\end{array}$ & 548.49 & 0.988 \\
\hline $\begin{array}{l}V_{35} \\
\text { DEA }\end{array}$ & $\begin{array}{c}0.94 \\
(19.690)^{* *}\end{array}$ & $\begin{array}{c}0.01 \\
(0.120)\end{array}$ & $\begin{array}{c}-0.29 \\
(-3.336)^{*}\end{array}$ & $\begin{array}{c}-0.11 \\
(-1.012)\end{array}$ & $\begin{array}{c}0.14 \\
(1.168)\end{array}$ & $\begin{array}{c}0.09 \\
(0.676)\end{array}$ & 67.23 & 0.911 \\
\hline
\end{tabular}

**Significant at the 0.01 level. *Significant at the 0.05 level. 


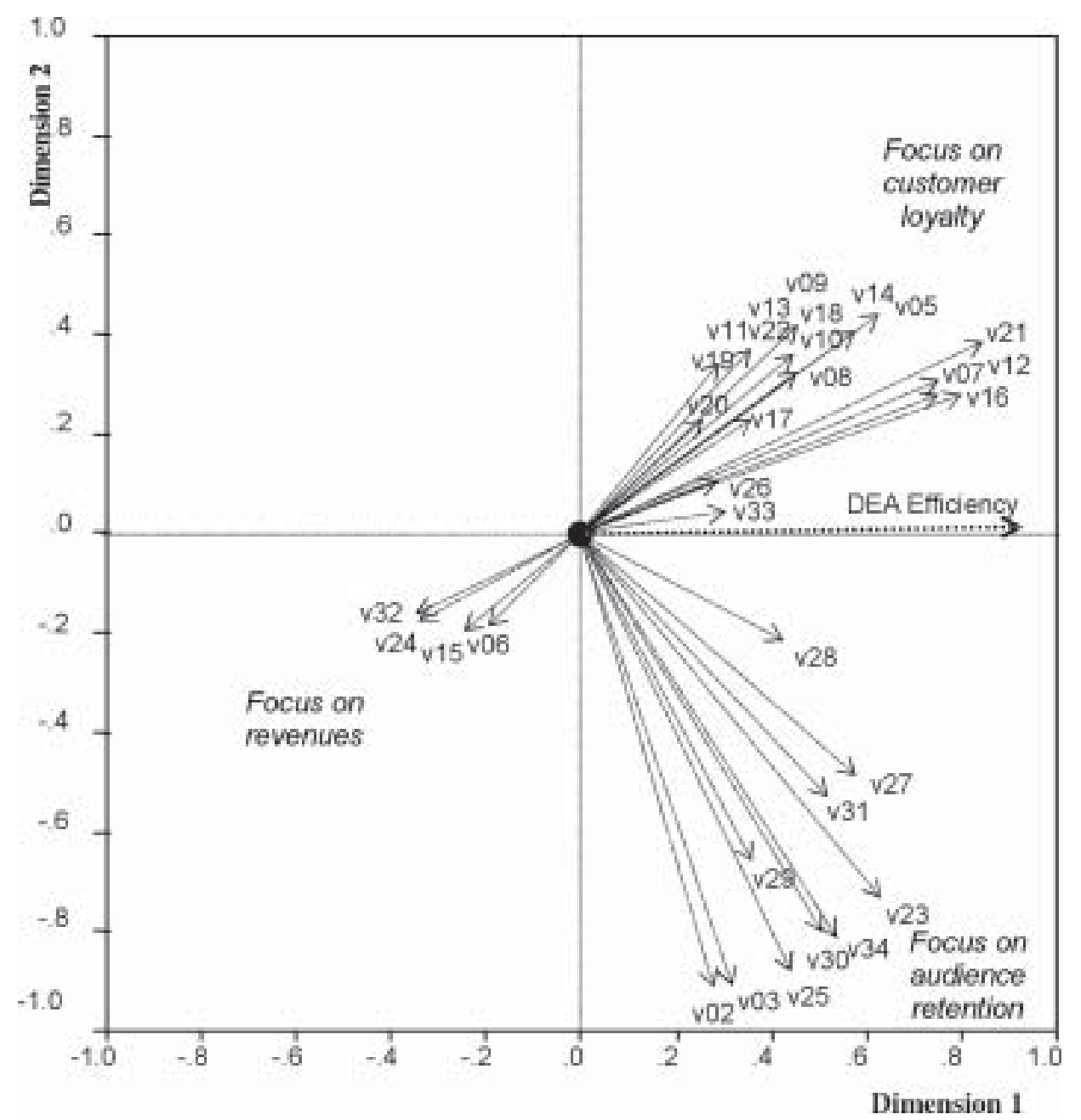

Figure 2. PF Analysis. Vectors for each variable. Dimension 1 and 2.

Most vectors point towards the right hand side of Figure 2. Recalling the parallel between PCA and MDS, the first dimension captures the first principal component, which is often taken as a general indicator of the main features in the data. The directional vector associated with DEA results follows the positive direction of Dimension 1 indicating that this dimension is related to productive efficiency. Also in the positive direction of Dimension 1, but on the negative side of Dimension 2, one finds a set of vectors related to ratios including the number of page hits or time spent (V23, V25, V27, V29, V30, V31 and V34). Other salient ratios are page hits per visitor (V2) and average time spent per visitor (V3). 
Continuing on the positive side of Dimension 1, but on the positive side of Dimension 2, one finds vectors corresponding to ratios including unique visitors or reach (V5, V7, V8, V9, V10, V11, V12, V13, V14, V16, V17, V18, V19, V20, V21 and V22).

It appears that Dimension 1 can be interpreted as efficiency as calculated by the DEA algorithm and the way in which this efficiency is obtained. DEA uses web metrics as outputs, and various accounting items as inputs. Firms that achieve high web metrics with low expenditure or with a cheap infrastructure will be identified as efficient by the DEA algorithm. Ratios involving a web metric in the numerator and an accounting item in the denominator can be viewed as partial performance indicators. DEA combines all aspects of performance into a single measure.

Figure 1 shows that there are various ways of achieving efficient use of resources. A possibility, as in the bottom right hand side quadrant, is to aim for a high number of page hits, as is the case with YHOO, and EBAY. EBAY is the leader in Internet auctions, and its visitors spend long periods of time connected. YHOO, the leading Internet portal and directory, is visited in order to conduct searches or obtain information on the most diverse subjects. These companies were identified as having $100 \%$ efficiency in section 2.3. A second way of achieving a high level of efficiency is to concentrate on obtaining fidelity from unique visitors. This happens in the top right-hand side quadrant of Figure 1. Firms in this quadrant are ONHN and LFMN. LFMN cater for various communities where visitors can access specialized information and resources. ONHN offers its visitors specialized medical information. These two firms were also identified as 100\% efficient in Section 2.3. Dimension 1, thus measures an internal organization intangible asset that can be labelled "management efficiency in achieving an impact on the Internet". It is to be noticed that this intangible asset can be measured in two different ways, which appear to be equivalent: management efficiency rankings can be computed either through DEA, or through the value of the coordinate in Dimension 1.

The above discussion opens the way to the interpretation of Dimension 2. Towards the bottom of this dimension appear page hits per visitor (V2), and average time spent per visitor (V3). Both are pure web metric variables. It can also be 
argued that towards the bottom of Figure 1 we have firms that attempt to attract customers and keep them operating in their servers. They offer popular general services that everybody knows and anyone can access. They attract passing birds that take the opportunity to rest from their journey. This is an external structure intangible asset that could be labelled "audience retention". Towards the top of Figure 1 we find highly specialized companies whose aim is customer loyalty. This is another external structure intangible asset: "customer loyalty". Thus, Dimension 2 is associated with two different ways of creating an external intangible asset: image/customer.

It is worth thinking for a moment about a group of companies situated on the left hand side of Dimension 1. This is a group formed by e-tailers (FATB, EGGS, BUYX, AMZN, ADBL). Both DEA and the position along Dimension 1 reflect the fact that, if efficiency is measured by the way in which financial resources are used to produce web metrics, these appear to be very inefficient firms. As previously argued, these firms are interested in obtaining unique visitors, as these are potential customer, but one must remember that their business is based on Internet selling and not on advertising. Further insight about them can be obtained by looking at Figure 2. Vectors that point in the direction of these six firms in Figure 2 include revenues in the numerator (V6, V15, V24, and V32). E-tailers should, then, be considered a separate strategic group for which the selected web metrics, relevant as they are, are less important. This has been studied by Fuertes et al. (2002) who found that revenues and visitors are very different objectives, almost opposed. Had we been satisfied with a simple DEA calculation all that we would have found is that these firms are inefficient. By setting the DEA results within the context of the financial ratios by means of a MDS representation, we have been able to interpret the reasons why they appear to be represented where they are. This is clearly a strength of the present methodology.

Dimension 3 was associated with V8 (gross profit/reach), V17 (gross profit/ unique visitors), V26 (gross profit/page hits), and V33 (gross profit/time spent). It can be deduced from this that this dimension is relating web metrics to profit.

The position on Dimension 4 appeared to be related to the structure of costs within the firm. Important ratios are V20, and V21. These ratios have web metrics in the numerator, and costs in the denominator ( $\& \& D$, and total operating expenses). 
The remaining dimensions (5 and 6) are only of marginal importance, as they explain less than $5 \%$ of the variance of the data. Dimension 5 was interpreted by making reference to cash flow considerations (V9 and V18) versus liabilities (V22, V13, and V31). Dimension 6 appears to be associated with V4 (average time spent per visitor), although the relevant $\mathrm{R}^{2}$ is low, 0.542 ; it might be more sensible not to look for interpretations, which might be spurious, and to threat this dimension as residual variation.

Examining projections on two dimensions can be deceptive, as two points may be far apart in the space but project next to each other in the configuration. This is why it is recommended to supplement a MDS analysis with the results of Hierarchical Cluster Analysis (HCA); Arabie et al (1987) and Chatfield and Collins (1980). The identification of strategic groups with the help of HCA is common practice; Houthoofd and Heene (1997), Flavian et al. (1998), and Serrano Cinca (1998). Companies were clustered using the same standardized 34 variables and the same measure of dissimilarity that had been employed to build the MDS configuration. Ward's clustering method was employed as it maximizes withingroup homogeneity and between-group heterogeneity. The dendrogram was calculated, and several distinctive groups were found. As can be seen in Figure 3, which shows the dendogram, there are two main groups of companies. These are associated with efficient and inefficient firms. The two groups divide in three groups each, making a grand total of six groups.

The results of the dendogram have been superimposed on Figure 1. Group 1 is formed by YHOO and EBAY. These firms are salient in Dimension 1 (efficiency in achieving an impact on the Internet) and Dimension 2 (audience retention). Group 2 contains ONHN, SWBD, ASKJ, TVLY, and UPRO. These are also efficient, and are located on the right hand side of Figure 1. Group 3 contains seven firms: CNET, SPLN, BOUT, MQST, TGLO, GOTO, and LFMN. This is a mixed group of firms from the point of view of DEA efficiency. Groups 2 and 3 are located towards the top of Dimension 2, salient in "customer loyalty". As far as the least efficient firms are concerned, they can be found towards the left of Figure 1. Here we find the three e-tailers of group 6 (BUYX, EGGS, and FATB). They are the least efficient at achieving an impact on the Internet. We also find ADBL and MCNS (group 5) and a very large cluster which was associated with the bulk of the companies (group 4). 


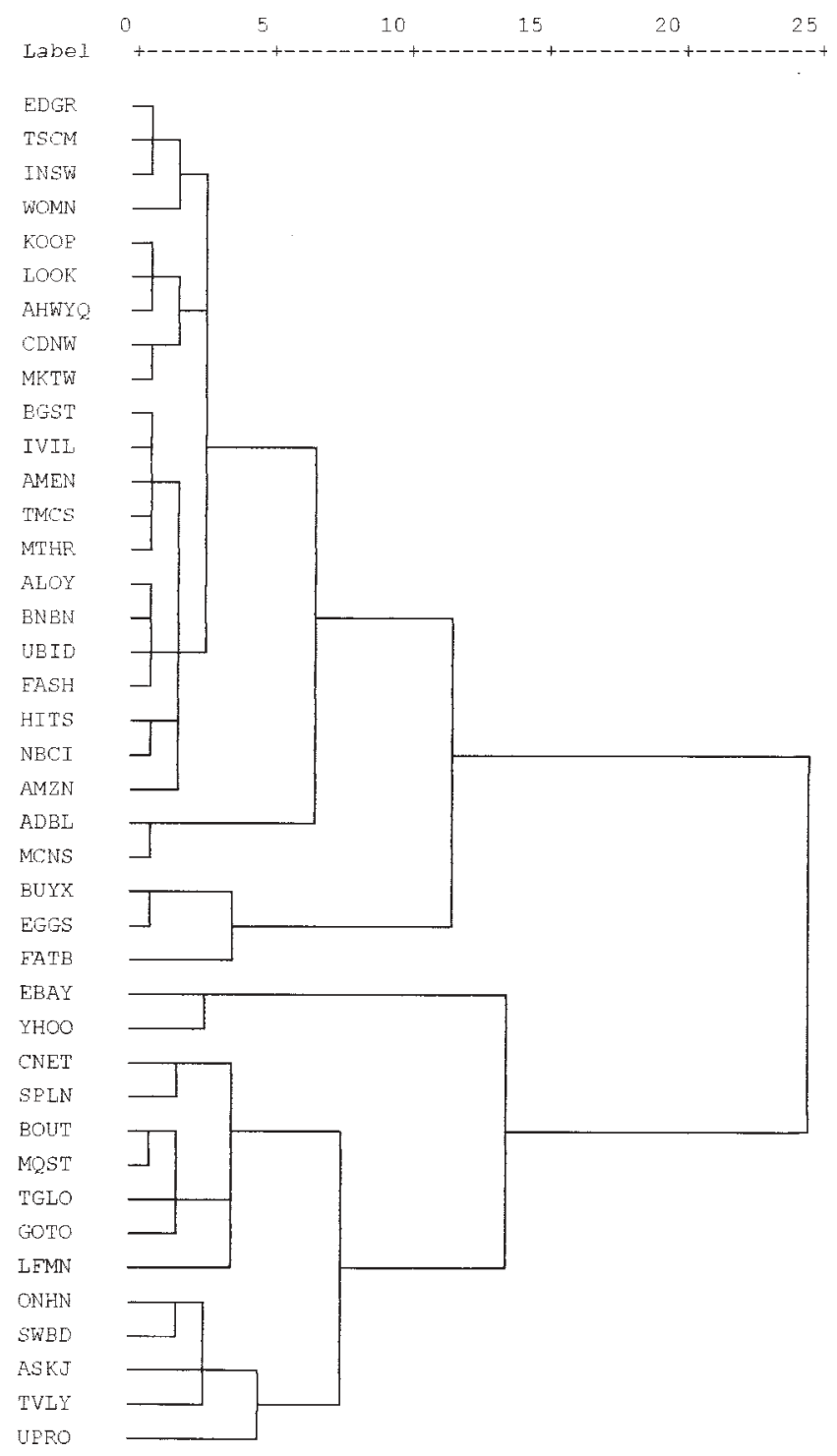

Figure 3. Dendrogram. Ward's method.

\section{CONCLUSIONS}

This paper has been concerned with dot com companies, intangible assets, efficiency measurement, and strategic patterns of behaviour. A sample of 40 companies that shared the characteristics of operating on the Internet, publishing annual accounts, and are listed in the stock exchange was studied. 
The study was based on web traffic measures, and ratios that involved the relationship between web metrics and accounting items.

The issue of efficiency was addressed by means of Data Envelopment Analysis (DEA). For each company, a DEA measure of efficiency is obtained by treating total operating expenses, total assets, number of employees, and total liabilities as inputs in the DEA model. Reach, unique visitors, page hits, and time spent were treated as outputs.

Comparative efficiency thus calculated was interpreted by making reference to 34 variables which were a mixture of web metrics and financial information. Modelling was based on multivariate statistical methods, in particular Multidimensional Scaling (MDS), which has the property of visualizing the main features of the data through statistical maps. Such maps were interpreted with the help of Hierarchical Cluster Analysis (HCA), and Property Fitting (PF), a regression based approach.

The statistical maps were built in a six dimensional space, but the first two dimensions were found to be of particular relevance, and could be interpreted as measurements of intangible assets. The first dimension was found to be related to an intangible asset of internal structure identified as management efficiency to achieve an impact on the Internet. The use of MDS made it possible to visualise the results in the form of a map, something that makes them accessible to the nonspecialist in multivariate analysis. It has also been possible to rank firms in order of efficiency, even when firms are $100 \%$ efficient. The second dimension was found to be associated with an intangible asset of external structure identified as customer/image. This second dimension had two aspects. On one direction it identified companies that attracted and kept the passing customer, and on the other direction it identified companies that provided specialised services for subscribers. It has also been observed that e-tailers should be treated as a separate strategic group, since web metrics such as "page hits" or "unique visitors", relevant as they are, are not as salient as in the rest of the industry.

From the methodological point of view, it has been shown that multivariate statistical methods make it possible to visualise what is behind an efficiency score. This use of quantitative tools opens the way to qualitative analysis of intangible assets and opens new avenues to accounting research. 


\section{REFERENCES}

ABOODY, D.; LEV, B. (1998): "The Value-Relevance of Intangibles: The Case of Software Capitalization”, Journal of Accounting Research, Supplement, 1998, pp. 161-191.

ALPAR, P.; POREMBSKI, M.; PICKERODT, S. (2001): "Measuring the Efficiency of Web Site Traffic Generation", International Journal of Electronic Commerce, vol. 6, n. 1, pp. 53-74

AMIR, E.; LEV, B. (1996): "Value-relevance of nonfinancial information: The wireless communications industry", Journal of Accounting and Economics, vol. $22,1-3,3-30$.

ARABIE, P.; CARROLL, J.D.; DESARBO, W.S. (1987): Three-way scaling and clustering, Sage University Paper Series on Quantitative Applications in the Social Sciences, number 07-065. Beverley Hills: Sage Pubns.

BAILEY, K.E.; BYLINSKY, J.H.; SHIELDS, M.D. (1983): "Effects of audit report wording changes on the perceived message", Journal of Accounting Research, vol. 21, 355-370.

BARTH, M.; CLINCH, G. (1998): "Revalued Financial, tangible and intangible assets: Associations with share prices and non-market-based value estimates", Journal of Accounting Research, vol. 36, Supplement 1998: 199-233.

BARTOV, E.; MOHANRAM, P.; SEETHAMRAJU, C. (2002): "Valuation of Internet Stocks-An IPO Perspective", Journal of Accounting Research, vol. 40, n. 2, pp.321-346.

BELKAOUI, A.; COUSINEAU, A. (1977): "Accounting information, nonaccounting information and common stock perception", Journal of Business Finance, vol. 50, 334-343.

BELKAOUI, A. (1980): "The interprofessional linguistic communication of accounting concepts: an experiment in sociolinguistics", Journal of Accounting Research, vol. 18, 362-374. 
BROOKING, A. (1996): Intellectual Capital, International Thomson Business Press. Thomson Learning Europe

BROWN, P.R. (1981): "A descriptive analysis of select input bases of the Financial Accounting Standards Board", Journal of Accounting Research, vol. 19, 232246.

CHARNES, A.; COOPER, W.; RHODES, E. (1978): "Measuring the efficiency of decision making units". European Journal of Operational Research, vol. 2, 429-444.

CHATFIELD, C.; COLLINS, A.J. (1980): Introduction to Multivariate Analysis. Chapman and Hall, London.

DAMORADAN, A. (2001): The Dark Side of Valuation: Valuing old tech, new tech, and new economy companies, (1st ed) Prentice Hall, New Jersey.

DAVILA, A.; VENKATACHALAM, M. (2001): Non-financial performance measures and CEO compensation: An analysis of web traffic. Working paper, University of Stanford.

DAVIS, A. (2002): "The Value Relevance of Revenue for Internet Firms: Does Reporting Grossed-up or Barter Revenue Make a Difference?", Journal of Accounting Research, vol. 40, n. 2, pp. 445-477

DAY, D.L.; DESARBO, W.S.; OLIVA, T.A. (1987): "Strategy maps: a spatial representation of intra-industry competitive strategy", Management Science, vol. 33, pp. 1534-1551.

DEMERS, E.; LEV, B. (2001): “A rude awakening: Internet shakeout in 2000”, Review of Accounting Studies, vol. 6, pp. 331-360.

DENG, Z.; LEV, B.; NARIN, F. (1999): "Science \& Technology as Predictors of Stock Performance”, Financial Analysts Journal, May-June, pp. 20-32.

EDVINSSON, L.; MALONE, M. (1997): Intellectual Capital. Realizing your company"s true value by finding its hidden brainpower, Harperbusiness, New York 
EMERY, D.R.; BARRON, F.H.; MESSIER, W.F. (1982): “Conjoint measurement and the analysis of noisy data: a comment", Journal of Accounting Research, vol. 20, pp. 450-458.

EZZAMEL, M.; MAR MOLINERO, C. (1990): "Distributional properties of financial ratios: evidence from UK manufacturing companies", Journal of Business Finance and Accounting, vol. 17, pp. 1-30.

FARE, R.; GROSSKOFT, S.; LOVELL, C.A.K. (1994): Production frontiers. Cambridge University Press. Cambridge, UK

FLAVIAN, C.; HABERBERG, A.; POLO, Y. (1998): "Subtle strategic insights from strategic groups analysis", Journal of Strategic Marketing, vol. 7, pp. 1-18.

FRANK, W.G. (1979): “An empirical analysis of international accounting principles", Journal of Accounting Research, vol. 17, pp. 593-605.

FUERTES, Y.; SERRANO CINCA, C.; MAR MOLINERO, C. (2002): "Measuring DEA efficiency in Internet companies", I International Conference: The Transparent Enterprise. The Value of Intangibles, E*Know-net, November, Madrid,

GANLEY, J.A.; CUBBIN, J.S. (1992): Public sector efficiency measurement. North Holland, New York.

GREEN, P.E., MAHESHWARI, A. (1969): "Common stock perception and preference: an application of Multidimensional Scaling”, Journal of Business, vol. 42 , pp. 439-457.

HAND, J. (2001): "The Role of Book Income, Web Traffic, and Supply and Demand in the Pricing of U.S. Internet Stocks", European Finance Review, vol. 5, n. 3, pp. 295-314

HIGSON, C.; BRIGINSHAW, J. (2000): "Valuing Internet Business", Business Strategy Review, vol. 11, n. 1, pp. 10-20

HODGKINSON, G.P.; TOMES, A.; PADMORE, J. (1996): "Using consumer perceptions for the cognitive analysis of corporate-level competitive structures", International Journal of Retail and Distribution Management, vol. 26, pp. 2-21. 
HOUTHOOFD, N.; HEENE, A. (1997): "Strategic groups as subsets of strategic scope groups in the Belgian brewing industry", Strategic Management Journal, vol. 18, pp. 653-666.

JORION, P.; TALMOR, E. (2001): "Value Relevance of Financial and Non Financial Information in Emerging Industries: The Changing Role of Web Traffic Data", 2001 Annual Meeting American Accounting Association, August 12-15, Atlanta, GA.

KEATING, E.K.; LYS, T.; MAGEE, R. (2003): "The Internet Downturn: Finding Valuation Factors In Spring 2000", Journal of Accounting \& Economics, vol. 34, pp 189-236

KRISTEN, E.; GREGORY, W. (1999): "Intangible assets and stocks prices in the pre-SEC Era", Journal of Accounting Research, Vol. 37 Supplement 1999, 17-44.

KRUSKAL, J.B. (1964): "Multidimensional Scaling by Optimizing Goodness of Fit to a Nonmetric Hypothesis", Psychometrika, n. 29, pp. 1-27.

KRUSKAL, J.B.; WISH, M. (1978): Multidimensional scaling. Sage University Paper series on Quantitative Applications in the Social Sciences, number 07-011. Sage Publications, Newbury Park, CA

LAND, A. (1991): Data Envelopment Analysis. Chapter 5 in SC Littlechild and MF Shuttler (ed) Operations Research in Management, Prentice Hall.

LEV, B. (1999): "R\&D and Capital Markets", Journal of Applied Corporate Finance, winter 1999, pp. 21-35.

LEV, B. (2002): "Where have all of Enron"s intangibles gone?", Journal of Accounting and Public Policy, vol. 21, pp 131-135

LIBBY, R. (1979): "Banker's and auditor's perceptions of the message communicated by the audit report", Journal of Accounting Research, vol. 17, pp. 99-122.

MAR MOLINERO, C.; APELLÁNIZ, P.; SERRANO-CINCA, C. (1996): "Multivariate Analysis of Spanish Bond Ratings", Omega, vol. 24, n. 4, pp. 451462 
MAR MOLINERO, C.; EZZAMEL, M. (1991): "Multidimensional scaling applied to company failure", Omega, vol. 19, pp. 259-274.

MAR MOLINERO, C.; SERRANO CINCA, C. (2001): "Bank failure: a multidimensional scaling approach", European Journal of Finance, vol. 7, n. 2, pp. $165-183$

MORIARITY, S.; BARRON, F.H. (1976): "Modelling the materiality judgements of audit partners", Journal of Accounting Research, vol. 14, pp. 320-341.

NORMAN, M.; STOCKER, B. (1991): Data Envelopment Analysis: the assessment of performance, John Wiley and Sons, Chichester.

ROCKNESS H.O.; NIKOLAI, L.A. (1977): “An assessment of APB voting patterns", Journal of Accounting Research, vol. 15, pp. 154-167.

SCHIFFMAN, J.F.; REYNOLDS, M.L.; YOUNG, F.W. (1981): Introduction to Multidimensional Scaling: Theory, Methods and Applications. Academic Press, London.

SCHWARTZ, E.S; MOON, M. (2000): "Rational Pricing of Internet Companies", Financial Analysts Journal, vol. 56, n. 3, pp. 62-75.

SERRANO CINCA, C. (1998): "From Financial Information to Strategic Groups - a Self Organizing Neural Network Approach", Journal of Forecasting, vol. 17, pp. 415-428.

SERRANO CINCA, C.; MAR MOLINERO, C.; BOSSI, A. (2003): “An approach to the measurement of intangible assets in public sector using scaling techniques", Journal of Intellectual Capital, vol. 4, n. 3

SERRANO CINCA, C.; MAR MOLINERO, C.; GALLIZO, J.L. (2002): “A multivariate study of the EU economy via financial statements analysis", Journal of the Royal Statistical Society, D, vol. 51, pp. 1-20

STEWART, T. (1998): Intellectual Capital: The new wealth of organizations, Bantan Books. 
SVEIBY, K. (1997): The Invisible Balance Sheet: Key Indicators For Accounting, Control And Evaluation Of Know-How Companies, The Konrad Group, Sweden.

THOM, R. (1989): Structural stability and morphogenesis. Redwood City, Calif: AddisonWesley.

TRUEMAN, B.; WONG, M.H; ZHANG, X. J. (2000): "The eyeballs have it: Searching for the value in Internet stocks," Journal of Accounting Research (Supplement), pp. 137-162.

TRUEMAN, B.; WONG, M.H; ZHANG, X. J. (2001): "Back to basics: Forecasting the revenues of Internet firms", Review of Accounting Studies, vol. 6, pp. 305329. 